\title{
The Association of Fever and Antibody Response in Rabbits Immunized with Human Serum Albumin *
}

\author{
Peter D. Mott and Sheldon M. Wolff $\dagger$ \\ (From the Clinical Physiology Section, Laboratory of Clinical Investigations, National \\ Institute of Allergy and Infectious Diseases, Bethesda, Md.)
}

The majority of studies of the pathogenesis of fever have been concerned with the elucidation of the febrile reaction after administration of bacterial endotoxins to animals and man (1). Recently, evidence has been cited to support the theory that endotoxin-induced fever itself may be related to immune mechanisms (2). Fever is, moreover, a frequent manifestation of certain clinical illnesses in which antigen-antibody interactions are considered to play a role. It is of interest, therefore, that the production of fever in rabbits immunized with a nonbacterial protein antigen, bovine serum albumin, has been related to antibody production and is similar in many respects to that seen after endotoxin administration $(3,4)$.

The present studies were designed to investigate the relationship of fever to antibody response in rabbits immunized with human serum albumin and to compare fever in this model system to that induced by bacterial endotoxins.

\section{Methods}

Rabbits. More than 400 New Zealand albino rabbits of either sex, from the same colony (National Institutes of Health), weighing approximately $2 \mathrm{~kg}$ each, were used throughout. Animals were housed in air-conditioned quarters and tested in the same room.

Recording of temperature. Temperatures (degrees Centigrade) were monitored with thermistors connected to a recording telethermometer 1 and inserted 4 to 6 inches into the rectum. Rabbits were trained for 5 to 8 hours in wooden stocks with loosely fitting collars on the day before testing. To insure a steady base line on

* Submitted for publication August 19, 1965; accepted December 2, 1965.

Presented in part at the Fifty-seventh Annual Meeting of the American Society for Clinical Investigation ( $\mathrm{J}$. clin. Invest. 1965, 44, 1077).

$\dagger$ Address requests for reprints to Dr. Sheldon M. Wolff, Bldg. 10, Room 11N-313, National Institutes of Health, Bethesda, Md. 20014.

1 Yellow Springs Instrument Co., Yellow Springs, Ohio. the day of testing, we recorded temperatures for at least 1 hour before injection; animals with temperatures below 38.5 or above $39.9^{\circ} \mathrm{C}$ were excluded. Febrile responses were plotted on $1-\times 1$-inch standard graph paper; 1 hour and $1^{\circ}$ each equaled 1 inch. Mean temperature elevations were obtained by averaging all rabbits within each group whether febrile or afebrile. The area in centimeters squared, fever index (FI), under a 5-hour fever curve, was measured with a compensating polar planimeter. $^{2}$ In the calculation of data, fever is defined as a temperature elevation above base line that occurs within the first $1 \frac{1}{2}$ hours and during the next 5 hours begins to return towards base line: This latter requirement could be invalidated when large febrile responses were encountered such as occur with large doses of endotoxin; however, no such large responses were recorded during these studies.

Immunization. A $5 \%$ solution of human serum albumin (HSA) ${ }^{3}$ was diluted with sterile saline to form immunizing ( $25 \mathrm{mg}$ per $\mathrm{ml}$ ) and challenging $(2,5,25$, and $50 \mathrm{mg}$ per $\mathrm{ml}$ ) doses. The solution of HSA was found by electrophoresis to be $97.2 \%$ albumin and conformed to the minimal requirements for human use as defined by the Division of Biologics Standards. Every time HSAimmunized rabbits were challenged, some normal rabbits received the HSA solution to insure that it was pyrogen free. Rabbits were given three iv injections of $25 \mathrm{mg}$ HSA per week for 3 weeks. Ten days later a challenge dose was administered intravenously, at which time temperatures were recorded.

Febrile tolerance to HSA was induced in immunized rabbits by administering eight daily iv injections of HSA beginning 10 days after the last immunizing dose, temperatures being recorded on the first and last days.

Endotoxin tolerance. Endotoxin tolerance was produced by ten daily iv injections of $2 \mu \mathrm{g}$ of Salmonella typhosa 0901 endotoxin (lot no. 458447),4 diluted in sterile, pyrogen-free phosphate-buffered saline ( $\mathrm{pH} 7.4)$ to a $1-\mathrm{ml}$ volume.

Injections and bleedings. All injections were into marginal ear veins. Sterile, pyrogen-free, disposable needles, syringes, and glassware were used throughout. All bleedings except those for passive transfer studies were from marginal ear veins, obtained either 24 hours before HSA challenge in the fever production studies

2 Keuffel and Esser, model 4242, Hoboken, N. J.

3 Courtland Laboratories, Los Angeles, Calif.

4 Difco Laboratories, Detroit, Mich. 
TABLE I

Association of fever and antibody response in human serum albumin (HSA)-immunized rabbits challenged with $H S A$

\begin{tabular}{lcc}
\hline \hline $\begin{array}{c}\text { Temperature } \\
\text { response }\end{array}$ & $\begin{array}{c}\text { Antibody } \\
\text { present }\end{array}$ & $\begin{array}{c}\text { Antibody } \\
\text { absent }\end{array}$ \\
\hline Fever & $45^{*}(1: 42.8) \dagger$ & 5 \\
No fever & $5(1: 2.0) \dagger$ & 8 \\
\hline
\end{tabular}

* Number of rabbits.

† Geometric mean titer (bentonite flocculation).

("immune" sera) or 24 hours after the last HSA injection in the febrile tolerance studies ("tolerant" sera). Sera for passive transfer were obtained at the same two times by intracardiac puncture with exsanguination under ether anesthesia with sterile precautions. The blood was allowed to clot and centrifuged and the serum stored at $-20^{\circ} \mathrm{C}$ until used.

Passive transfer studies. Serum was thawed, warmed to $37^{\circ} \mathrm{C}$ for 30 minutes, and infused via marginal ear veins in doses of 10 and $20 \mathrm{ml}$ per $\mathrm{kg}$, temperatures being recorded in the usual manner. Normal animals receiving immune whole sera were challenged 24 hours later, temperatures being recorded on both days. Immunized rabbits receiving tolerant whole sera 10 days after their last immunizing dose were challenged 2 to 3.8 hours after the serum infusion. Normal animals receiving fractionated sera were challenged 24 hours later, temperatures being recorded on both days.

Antibody determinations. Bentonite particles were coated with HSA, and flocculation by serial twofold dilutions of serum or of fractionated sera was observed (5, $6)$. The antigen binding capacities (ABC) at 0.2 and $0.02 \mu \mathrm{g} \mathrm{N}$ per $\mathrm{ml}$ of antigen were determined on 31 sera as previously described (7)..$^{5}$ The effect of dilution on the $\mathrm{ABC}$ was expressed as the ratio of the $\mathrm{ABC}$ at 0.02 and $0.2 \mu \mathrm{g} \mathrm{N}$ per $\mathrm{ml}$, respectively (7).

Gel filtration. Sephadex G-200 gel filtration was carried out with normal, immune, or tolerant pooled serum specimens of 3 to $50 \mathrm{ml}$ each, which had previously been spun for 30 minutes at $20,000 \mathrm{rpm}$ in a Spinco model L ultracentrifuge, the upper third being discarded. These specimens were applied to a glass column $125 \mathrm{~cm}$ in length, holding $2.4 \mathrm{~L}$ of Sephadex G-200 gel packed by gravity and perfused by sterile $0.1 \mathrm{M}$ sodium chloride (buffered with $10 \%$ by volume of borate buffer, $\mathrm{pH} 8.0$ ). The flow rate was 15 to $50 \mathrm{ml}$ per hour, the eluate passing continuously through a recording spectrophotometer ${ }^{6}$ measuring protein concentration by absorption at $280 \mathrm{~m} \mu$. The contents of all collecting test tubes corresponding to the initial $70 \%$ of Fraction I and the last $70 \%$ of Fractions II and III were pooled with the addition of $1 \mathrm{ml}$ of $1 \%$ Merthiolate per $\mathrm{ml}$ of eluate, reconcentrated in dialysis tubing subjected to negative pressure to approximate the original serum volume, and stored at $-20^{\circ} \mathrm{C}$.

5 The determinations were kindly made by Dr. Richard S. Farr.

6 Gilson Medical Electronics. Middleton, Wis.
TABLE II

Effect of (HSA) challenge dose in HSA-immunized rabbits

\begin{tabular}{ccc}
\hline $\begin{array}{c}\text { Challenge } \\
\text { dose }\end{array}$ & $\begin{array}{c}\text { No. of } \\
\text { rabbits }\end{array}$ & $\begin{array}{c}\text { Temperature rise } \\
\text { at 1.5 hours }\end{array}$ \\
\hline$m g$ & & ${ }^{\circ} C$ \\
0.5 & 5 & $0.13 \pm 0.05^{*}$ \\
2 & 16 & $0.35 \pm 0.08$ \\
5 & 45 & $0.73 \pm 0.06$ \\
25 & 7 & $0.98 \pm 0.14$ \\
50 & 4 & $\dagger$ \\
\hline
\end{tabular}

* Mean \pm standard error.

† Two rabbits died of apparent anaphylactic shock, a third remained afebrile on challenge, and the fourth had a temperature elevation of $1.4^{\circ} \mathrm{C}$ at 1.5 hours.

Immunoelectrophoresis. Immunoelectrophoresis of the fractions obtained by gel filtration was carried out (8) as modified for microscope slides (9), with a goat antirabbit serum.

Reticuloendothelial system (RES) blockade. Thorium dioxide ${ }^{7}$ was given at a dose of $3 \mathrm{ml}$ per $\mathrm{kg}$ body weight intravenously 16 hours before the challenge injection of HSA.

\section{Results}

$H S A$ administration to normal rabbits. To exclude the possibility that the HSA solution contained pyrogenic contaminants, we gave normal rabbits a similar dose and recorded their temperatures each time HSA was administered as a challenge. A total of 66 rabbits were given $5 \mathrm{mg}$ of HSA on 19 different occasions, and only five developed any fever. The mean temperature rise at 1.5 hours was $0.21^{\circ} \mathrm{C} \pm 0.04$ (SE).

Febrile response of immunized rabbits to $H S A$ challenge. Ten days after the last of nine $25-\mathrm{mg}$ immunizing doses, rabbits were challenged with 2 or $5 \mathrm{mg}$ of HSA. As shown in Table I, 50 of 63 rabbits $(79 \%)$ responded to either challenge dose with fever; of those with fever 45 had detectable antibody. The remaining five rabbits that developed fever had no demonstrable antibody. Thirteen rabbits did not develop fever on challenge, and, of these, five had detectable antibody and eight had none (Table I).

As shown in Table II, a relationship exists between the quantity of antigen administered as challenge and the febrile response. After a 50-mg challenge, two rabbits died in apparent anaphylactic shock within 5 minutes of injection, one other developed a temperature rise of $1.4^{\circ} \mathrm{C}$, and another was afebrile. The latter was also the

\footnotetext{
7 Thorotrast, Testagar Co., Detroit, Mich.
} 


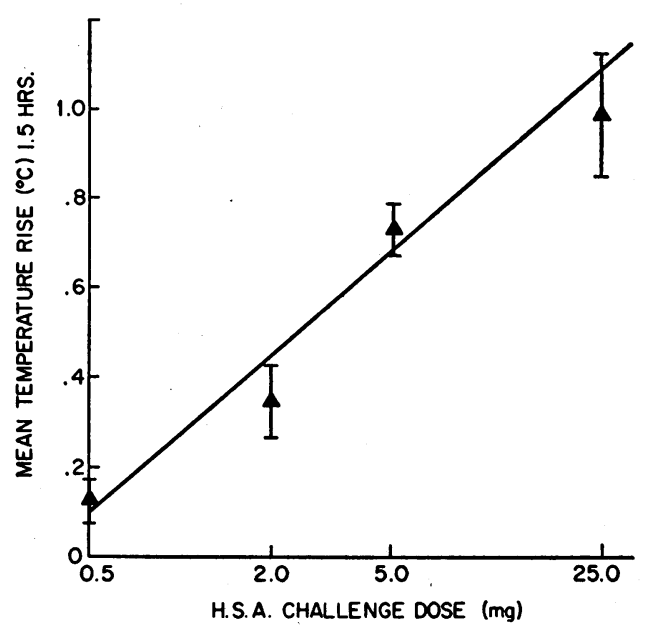

Fig. 1. Association between human Serum albuMIN (HSA) CHALLENGE DOSE AND FEBRILE RESPONSE IN IMMUNIZED RABBITS. The data are also presented in Table II. A significant correlation exists between challenge dose and febrile response (slope $=0.57 \pm 0.12, p<$ $0.01, t$ test). Each point is the mean \pm standard error.

only one in this group to have a negative antibody titer before challenge. The data from Table II are graphically presented in Figure 1 and show that a correlation exists between challenge dose and the febrile response of immunized animals (slope $=$ $0.57 \pm 0.12, \mathrm{p}<0.01, t$ test $)$.

Antibody response. Anti-HSA antibody titers, 9 days after the final immunizing dose and 1 day before challenge, were detectable in 50 of 63 rabbits (79\%) by the bentonite technique (Table I). When the individual bentonite antibody titers are plotted against the 1.5-hour temperature rise after a 5-mg challenge dose, it can be seen that there is an upward trend in fever associated with increasing antibody level $(r=0.516, p=0.02$, Spearman rank correlation test) (Figure 2 ).

Sera from the first 31 of the same 63 rabbits were tested for $A B C$. In contrast to the bentonite technique, the $A B C$ method detected some antibody in all 31 sera. However, the antibody determinations by the $\mathrm{ABC}$ method correlated closely with the bentonite titers $(r=0.875, p<$ 0.01 , Spearman rank correlation). The correlation between $\mathrm{ABC}$ and fever after a 2-mg challenge dose was significant $(r=0.592, p=0.02)$; after the 5-mg challenge similar results were obtained $(r=0.496, p=0.02)$. However, the effect of dilution upon the $A B C$ was not significantly correlated with the febrile responses to either 2 or 5 mg $(r=0.399, p=0.09, r=0.140, p=>.10$, respectively). Despite these differences, when the effect of dilution on the $A B C$ was compared to the bentonite titers, there was a significant positive correlation $(\mathrm{r}=0.608, \mathrm{p}<0.01)$.

Effect of booster injections of HSA. To determine whether further antigenic stimulation would increase the percentage of rabbits responding with fever or antibody, we gave booster injections to 18 immunized rabbits 3 and 4 weeks after initial challenge, when only $56 \%$ had responded with fever. After the last of these injections, fever was observed in only $63 \%$ of the rabbits. Thus, the number of afebrile rabbits remained approximately the same, although some that were afebrile on first challenge became febrile after the booster injections. The mean 1.5-hour temperature rise was increased from $0.41^{\circ} \mathrm{C}$ to $0.54^{\circ} \mathrm{C}$. Despite the administration of antigen, the antibody titers (bentonite flocculation) did not change significantly during the course of booster injections. Six rabbits remained afebrile after all HSA challenges, and these had no measurable antibody (bentonite flocculation) throughout the period of repeated challenge.

Characteristics of the fever curve. The latent period from the time of injection to the initial rise in temperature averaged 0.74 hour. In only eight of 63 febrile rabbits was the temperature curve biphasic, typical curves being monophasic with the peak of temperature rise occurring at 1.5 hours

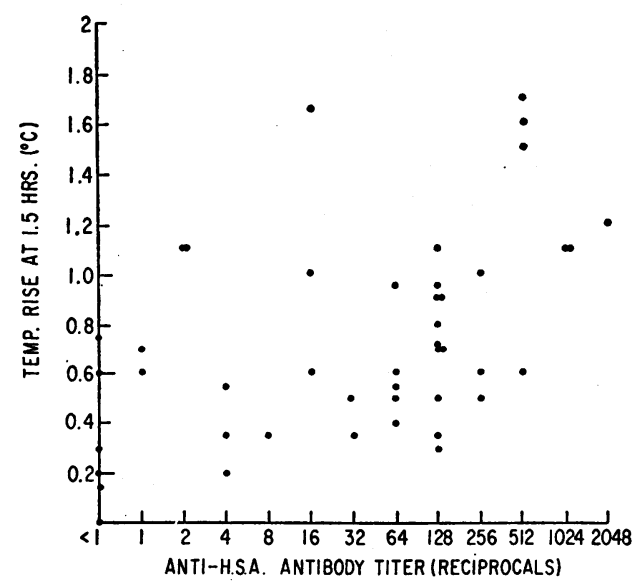

Fig. 2. Relationship of Bentonite flocculating ANTIBODY TITERS TO FEBRILE RESPONSES. Data presented are from individual immunized rabbits at time of challenge with $5 \mathrm{mg}$ of HSA. A significant correlation exists between antibody titer and febrile responsiveness. See text. 
TABLE III

Effect of endotoxin tolerance on HSA-induced fever

\begin{tabular}{|c|c|c|c|c|}
\hline Rabbits & $\begin{array}{c}\text { HSA } \\
\text { chal- } \\
\text { lenge } \\
\text { dose }\end{array}$ & $\begin{array}{l}\text { No. } \\
\text { febrile/ } \\
\text { Total }\end{array}$ & $\begin{array}{c}\text { Mean } \\
\text { temper- } \\
\text { ature } \\
\text { rise in } \\
1.5 \text { hours }\end{array}$ & $\begin{array}{l}\text { Anti- } \\
\text { body } \\
\text { titer* }\end{array}$ \\
\hline & $m g$ & & ${ }^{\circ} \mathrm{C}$ & \\
\hline HSA-immunized & 5 & $5 / 7$ & 0.58 & $1: 58.1$ \\
\hline $\begin{array}{l}\text { HSA-immunized and } \\
\text { endotoxin tolerant }\end{array}$ & 5 & $5 / 7$ & 0.38 & $1: 39.1$ \\
\hline
\end{tabular}

* Geometric mean antibody titers (bentonite flocculation).

and returning to base-line temperature after an average of 3.66 hours from the time of injection. When the second peak of the biphasic fever curve was noted, it occurred at 4 hours. There was a late rise in temperature, occurring with a peak at 4.6 hours in six rabbits. In nine animals there was an initial mean maximal decrease in temperature of $0.29^{\circ} \mathrm{C}$ occurring 0.43 hour after challenge, which probably represents transient anaphylaxis.

Effect of endotoxin tolerance on $H S A$-induced fever. HSA-immunized rabbits were made endotoxin tolerant by daily iv injections of bacterial endotoxin for 6 days before HSA challenge, and similarly immunized rabbits received no endotoxin to serve as controls. The results of these experiments are presented in Table III. Comparisons of the mean maximal temperature responses (1.5 hours) of both groups (Table III) and the mean of the group challenged with $5 \mathrm{mg}$ in previous experiments (Table II) revealed no significant difference ( $p=0.09, F$ test $)$. Furthermore, comparison of the mean response of the endotoxin tolerant immunized group to the immunized nontolerant group (Table III) demonstrated no significant differences $(\mathrm{p}=>0.20, t$ test).

Passive transfer of fever responsiveness. Sera from immunized animals were pooled according to similar bentonite flocculating antibody titers and infused intravenously into 41 normal recipients at a dose of $20 \mathrm{ml}$ per $\mathrm{kg}$ body weight. Eight normal rabbits received pooled normal sera and six received no serum. One day later all recipient and control rabbits were challenged with $5 \mathrm{mg}$ of HSA intravenously. As shown in Table IV, control rabbits and those receiving normal rabbit serum remained afebrile after challenge. After the administration of sera from rabbits immunized but without detectable antibody, one of seven rabbits responded to HSA challenge with a 1.5 -hour tem- perature rise of $0.50^{\circ} \mathrm{C}$. Of those receiving sera with detectable antibody, 23 of 34 rabbits became febrile on challenge $(68 \%)$. Fever in recipients of serum with measurable antibody was significantly greater than those that received no sera, normal sera, or sera without detectable antibody (titer $<1$ ) from immunized donors ( $p<0.01, t$ test). The pattern of febrile response was similar to that seen when immunized rabbits were challenged: the average latent period from time of challenge to onset of fever was 0.78 hour, the curves were monophasic, and the duration of fever was similar. The average 1.5 -hour temperature rise was $0.44^{\circ} \mathrm{C}$.

Production of febrile tolerance. In $49 \mathrm{immu-}$ nized rabbits that had responded with fever to an initial 2-, 5-, or 25-mg HSA challenge, the same dose was repeated daily for 8 days. Fever indexes decreased from the first to the eighth day in 39 of the 49 rabbits with the over-all average net change in FI being $-6.58 \mathrm{~cm}^{2}$. Seven rabbits were followed with daily temperature records, and the decrease in fever was seen to occur by the second day. A composite graph of the febrile responses of these seven rabbits on day 1 and day 8 , shown in Figure 3, illustrates the characteristic decrease in duration of fever during the production of tolerance. Maximal temperature rise was no less on day 8 , but the return toward base-line temperature occurred earlier. Therefore, the data are expressed in terms of fever index rather than mean 1.5-hour temperature rise. In eight rabbits that had biphasic fever curves after initial HSA challenge, the second peak of fever disappeared during

TABLE IV

Effect of passive transfer of serum from HSA-immunized donors upon the pyrogenic reactivity of normal rabbits to challenge with $H S A$

\begin{tabular}{lcc}
\hline \hline \multicolumn{1}{c}{$\begin{array}{c}\text { Antibody titer of } \\
\text { donor sera* }\end{array}$} & $\begin{array}{c}\text { No. } \\
\text { febrile/ } \\
\text { Total }\end{array}$ & $\begin{array}{c}\text { Mean maximal } \\
\text { temperature rise } \\
\text { in } 1.5 \text { hours }\end{array}$ \\
\hline & & ${ }^{\circ} C$ \\
No serum & $0 / 6$ & $0.11 \pm 0.05 \dagger$ \\
Normal rabbit serum & $0 / 8$ & $0.07 \pm 0.03$ \\
$<1 \ddagger$ & $1 / 7$ & $0.17 \pm 0.06$ \\
$1: 1-1: 2$ & $4 / 9$ & $0.33 \pm 0.12$ \\
$1: 4-1: 8$ & $5 / 6$ & $0.62 \pm 0.20$ \\
$1: 16-1: 64$ & $6 / 7$ & $0.26 \pm 0.07$ \\
$>1: 64$ & $8 / 12$ & $0.54 \pm 0.14$ \\
\hline
\end{tabular}

* Bentonite flocculation.

$\dagger$ Mean \pm standard error.

$\ddagger$ No detectable antibody despite immunization. 


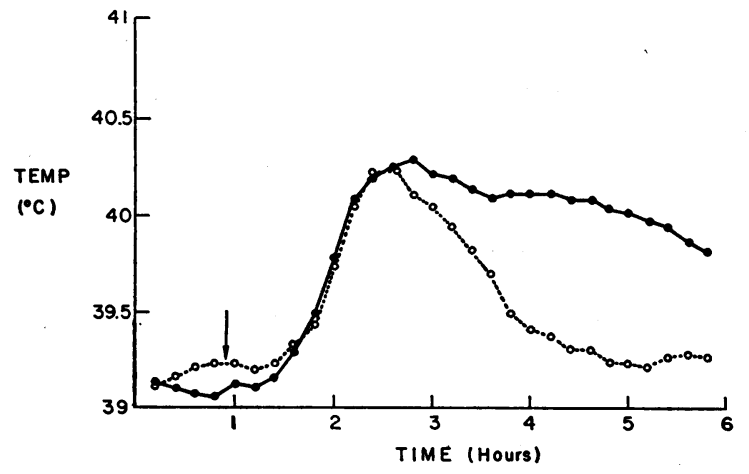

Fig. 3. Development of febrile tolerance to HSA IN IMMUNIZED RABBITS. The closed circles represent the mean temperature responses of seven rabbits during the first of a series of eight daily iv injections of $5 \mathrm{mg}$ of HSA. Open circles are the mean temperature responses of the same rabbits on day 8 .

the development of febrile tolerance. When four tolerant rabbits were given tenfold greater doses of HSA 1 day later, all animals developed apparent anaphylactic shock and three died.

Effect of RES blockade on febrile tolerance. Thorotrast was given to 11 tolerant rabbits on the eighth day of daily HSA injections. Sixteen hours after RES blockade the rabbits were challenged again with HSA, and fever indexes were exactly the same as on the previous day (i.e., FI were 12.1 $\mathrm{cm}^{2}$ before and $12.1 \mathrm{~cm}^{2}$ after Thorotrast).

Attempts to passively transfer febrile tolerance. Rabbits immunized with HSA in the usual manner and having antibody titers of greater than 1:2 were used as recipients. Immunized rabbits in which pyrogenic tolerance to HSA had been induced, as described above, served as donors. Nine immunized rabbits received $10 \mathrm{ml}$ per $\mathrm{kg}$ of tolerant serum and eight received normal serum. In another experiment, ten immunized rabbits received $20 \mathrm{ml}$ per $\mathrm{kg}$ of tolerant serum and five received normal serum. After the administration of $5 \mathrm{mg}$ of HSA, 2 to 3.8 hours after serum transfer, there was no demonstrable difference in febrile response among recipients of normal or tolerant serum or five immunized controls who had received no serum. It should be noted, however, that the fever curves of all of the recipients were monophasic, thus making the demonstration of passively transferred tolerance difficult.

Gel filtration studies. After Sephadex G-200 fractionation, immunoelectrophoresis verified that the $7 \mathrm{~S} \gamma$-globulin $(\gamma \mathrm{G})$ was in Fraction II, the $19 \mathrm{~S}$ macroglobulin $(\gamma \mathrm{M})$ was in Fraction I, and neither was detectable in Fraction III. The antibody determinations on the fractions from two different serum pools, which were also used for passive transfer studies, are given in Table V. A third specimen, not used for passive transfer studies, was also fractionated, and the antibody titers were 1:256 in Fractions I and II and 1:4 in Fraction III, which may represent overflow.

Serum from rabbits made tolerant to HSA was similarly fractionated with Fractions I, II, and III having antibody titers of $1: 32,1: 64$, and $<1$, respectively.

Passive transfer of serum fractions after gel filtration. After gel filtration, Fractions I, II, and III of immune serum were concentrated to approximate whole serum and infused intravenously into 24 normal rabbits at a dose of $20 \mathrm{ml}$ per $\mathrm{kg}$. All infusions evoked a pyrogenic response, which probably represents endotoxin contaminants or some dextran from which the Sephadex is made. Since, as noted above, endotoxin tolerance did not interfere with the expected pyrogenic response to challenge in immunized rabbits, these febrile responses can be disregarded. One day after passive transfer, however, the recipients were afebrile and were then challenged with $5 \mathrm{mg}$ of HSA. Five of the Fraction III recipients were bled 22 hours after receiving Fraction III, just before challenge, and none had detectable antibody. Immediately before challenge antibodies were measurable in all recipients of Fractions I and II, geometric mean titers being $1: 3.0$ and $1: 10.6$, re-

TABLE $V$

Effect of passive transfer of serum fractions of HSA-immunized donors upon febrile reactivity of normal rabbits to challenge with HSA*

\begin{tabular}{cccc}
\hline Fractions & $\begin{array}{c}\text { Antibody } \\
\text { titert }\end{array}$ & $\begin{array}{c}\text { Mean } \\
\text { maximal } \\
\text { febrile/ } \\
\text { Total }\end{array}$ & $\begin{array}{c}\text { temperature } \\
\text { rise in } \\
\text { 3 hours }\end{array}$ \\
\hline \multirow{2}{*}{ I } & $1: 1$ & $0 / 4$ & 0.30 \\
II & $1: 32$ & $3 / 5$ & 0.20 \\
& $1: 32$ & $1 / 3$ & 0.60 \\
III & $1: 32$ & $4 / 5$ & 0.48 \\
& $<1$ & $0 / 2$ & 0.05 \\
& $<1$ & $0 / 5$ & 0.09 \\
\hline
\end{tabular}

* Data supplied from two separate experiments. $\dagger$ Bentonite flocculation. 
spectively. As shown in Table $\mathrm{V}$, recipients of Fraction III had no fever. Although fever developed in some recipients of Fraction I, only the febrile responses after challenge in recipients of Fraction II were significantly different from control rabbits $(p=0.03$, Wilcoxon test $)$. The maximal temperature rise in 3 hours was used as an index of fever in this experiment because the peak of fever occurred at 3 rather than 1.5 hours. The delay in fever with the passive transfer of serum fractions is unexplained.

\section{Discussion}

Fever has been recognized for many years to be a frequent manifestation of certain hypersensitivity states. There have been relatively few studies, however, directed at understanding the pathogenesis of fever during immunologic reactions when compared to the numerous investigations concerned with bacterial endotoxin fever. In a series of experiments, Farr reported that more than one-half of rabbits immunized with bovine serum albumin (BSA) developed fever on subsequent challenge with antigen and that the fever resembled that seen after endotoxin $(3,4,10)$. It has also been reported that rabbits previously sensitized to sheep serum and egg-albumen developed fever on challenge with homologous antigen (11). In a study of the fever associated with blood transfusion reactions, leukocytes were administered to patients who had leukagglutinins with the development of fever, suggesting an immunologic mechanism for fever production in such patients (12). In a comprehensive series of experiments, Jandl and Tomlinson related febrile reactions after immune destruction of red blood cells to pre-existing titers of agglutinins or hemolysins (13). They found, on the other hand, that hemolysis induced by other nonimmunologic methods did not result in fever (13).

Fever may result from specific protein antigen challenge in animals manifesting delayed hypersensitivity. Stetson reported that old tuberculin administered to normal rabbits caused no fever, but, when given to animals sensitized to BCG vaccine, fever resulted (14). Hall and Atkins, working with the same model system, observed that a state of lessened febrile reactivity (i.e., pyrogenic tolerance) resulted from frequently repeated injections of the antigen (15). Uhr and Brandriss, using guinea pigs sensitized to a variety of protein antigens, observed the development of fever when homologous antigen was readministered (16). Although not a part of this investigation, it is possible that the immunized animals would also have manifested delayed hypersensitivity, in addition to circulating antibody.

The fever resulting from immunization with HSA is clearly an induced phenomenon, since the first iv injection of antigen is not pyrogenic. The induction of the capacity to respond with fever to antigen is not universal, and why $21 \%$ of immunized rabbits remained unresponsive is as yet unexplained. Unresponsiveness persisted despite subsequent booster injections of HSA. These findings are in striking contrast to those noted after the administration of bacterial endotoxins, since rabbits are rarely unresponsive to the pyrogenic and antigenic properties of these lipopolysaccharides when given in adequate amounts. Furthermore, fever occurs in endotoxin-treated animals on first exposure to the endotoxin, and antibodies begin to rise between 48 and 72 hours (17). The fact that in this study $21 \%$ of HSA-immunized animals produced no detectable bentonite flocculating antibody is also of interest, but may merely reflect the limits of sensitivity of this test, since all animals studied had some antibody by the $A B C$ method. Despite this latter fact, there was a highly significant correlation between the results obtained by both tests.

Using BSA, Farr found no direct correlation between total antibody content and fever, although animals without detectable antibody never developed fever upon challenge with BSA (10). He also reported that a relationship existed between the amount of fever elicited and the presence of antibodies that could not bind antigen efficiently in dilute solution (10); however, the effect of dilution was assessed by obtaining the differences of the $A B C$ at a very high concentration of antigen (10.7 $\mu \mathrm{g} \mathrm{N}$ per $\mathrm{ml}$ ) and a low concentration (0.02 $\mu \mathrm{g} \mathrm{N}$ per $\mathrm{ml}$ ) (18). In the present studies in which ratios of the $A B C$ were used to measure the effect of dilution, no such correlation was noted between fever and the effect of dilution on the capacity of anti-HSA antibody to bind antigen. The association is clear, however, between fever responsiveness and antibody levels by either the bentonite or $\mathrm{ABC}$ techniques. 
It has been reported previously that passively transferred sera from BSA-immunized donors conferred on the recipients the ability to respond with fever to antigenic challenge (19). In the present studies the sera from HSA-immunized donors that had no detectable bentonite flocculating antibody did not passively transfer to normal rabbits the ability to respond with fever when challenged. On the other hand, sera containing antibody conferred febrile responsiveness to normal recipients with an incidence similar to that seen in primarily immunized animals. Characteristics of the fever curve were also similar. These passive transfer studies further strengthen the concept that the fever elicited was due to the interaction of antigen and antibody.

It is clear that a quantitative relationship exists between challenge dose and febrile responsiveness. This finding is similar to the quantitative doseresponse relationship noted in normal rabbits receiving bacterial endotoxin (20). With certain endotoxins, however, further increasing the dose does not elicit more fever (i.e., there is a plateau in the dose-response curve) (20). On the other hand, the range between maximal pyrogenic responsiveness to HSA and anaphylaxis is quite narrow. Death after a large HSA challenge occurred within 5 minutes, whereas that seen with endotoxin occurs within 4 hours.

Although it was previously reported that similarities exist between certain characteristics of the febrile responses induced by BSA and those induced by endotoxin, some differences have been noted in the present studies. The latent period before temperature rise was longer than that found after endotoxin. The fever curve was usually monophasic as opposed to the biphasic pattern characteristic of endotoxin. As mentioned above, 21\% of rabbits will not respond with fever challenge. Prior induction of endotoxin tolerance did not affect the febrile response to HSA challenge. Maximal temperature elevation was small even with a challenge dose that caused anaphylaxis in $50 \%$ of rabbits. If larger HSA challenge doses could be employed, it is conceivable that the characteristics of the febrile response might more closely resemble those seen with endotoxin; however, this seems very unlikely because a small increase in HSA challenge dose results in anaphylaxis and death. In view of the above findings, the hypothesis that endotoxin-induced fever has an immunologic basis might be re-examined, since the similarities between BSA-induced and endotoxin fever have been cited as evidence in support of such a concept (2). It should be noted, however, that the latter concept is not universally accepted.

A state of decreased febrile reactivity (i.e., pyrogenic tolerance) could be readily induced in a manner similar to that noted when endotoxins, other protein antigens, tuberculoprotein, and other microorganisms were employed. Unlike endotoxin tolerance, however, febrile tolerance to HSA could not be passively transferred on two separate occasions. Furthermore, endotoxin tolerance conveys protection against ordinarily lethal doses of endotoxin, but no such protection exists with HSA tolerance. Thus, increasing the dose of HSA tenfold caused anaphylaxis in all and death in $75 \%$ of tolerant animals. These findings are in contrast to previous reports using BSA and are unexplained. The fact that blockade of the RES did not affect febrile tolerance induced by HSA is further substantial evidence of the difference between this state and endotoxin tolerance.

The fractionation of immune serum demonstrated that anti-HSA antibody was found in both Fractions I and II, with a slight expected predominance in Fraction II, which contains $7 \mathrm{~S} \gamma$-globulin. When these serum fractions were passively transferred to normal rabbits, febrile reactivity was found only in recipients of Fractions I and II, with a significantly greater responsiveness in recipients of Fraction II. These data would suggest that the $7 \mathrm{~S} \gamma$-globulin antibody reacting with HSA may be responsible for the fever elicited; however, this question must await further study.

\section{Summary}

Rabbits immunized with human serum albumin will respond with fever upon challenge with the antigen. The presence or absence of pyrogenic responsiveness was correlated with circulating antibody measured by two different techniques. A quantitative relationship existed, over a narrow range, between dose of antigenic challenge and fever. The febrile response was usually monophasic, followed a long latent period, was occasionally accompanied by initial hypothermia, and was not affected by prior induction of endotoxin tolerance. Febrile tolerance to human serum albumin 
was induced by daily repetition of the challenge dose, was not affected by reticuloendothelial system blockade, could not be passively transferred by serum, and did not protect rabbits from anaphylaxis when given a tenfold increase in challenge dose. The ability of certain immunized rabbits to respond to challenge with fever could be passively transferred to normal rabbits by whole serum only if antibody was detectable; it could also be transferred by Sephadex serum Fraction II, which contained $7 \mathrm{~S} \gamma$-globulin. These studies indicate the association between febrile reactivity and the presence of circulating antibody in rabbits immunized with human serum albumin. In contrast to previous reports utilizing bovine serum albumin as the antigen; these studies point out certain differences between the fever elicited by bacterial endotoxin and the pyrogenic responses after the administration of human serum albumin to rabbits immunized with human serum albumin.

\section{Acknowledgments}

The authors gratefully acknowledge the expert technical assistance of Messrs. S. B. Ward and J. Edelin. We are indebted to Dr. D. W. Alling for the statistical analyses and to Dr. R. S. Farr for the antigen binding capacity determinations.

\section{References}

1. Atkins, E. Pathogenesis of fever. Physiol. Rev. 1960, 40, 580.

2. Stetson, C. A. Role of hypersensitivity in reactions to endotoxin in Bacterial Endotoxins, M. Landy and W. Braun, Eds. New Brunswick, Rutgers University Press, 1964.

3. Farr, R. S., D. H. Campbell, S. L. Clark, Jr., and J. E. Proffitt. The febrile response of sensitized rabbits to the intravenous injection of antigen (abstract). Anat. Rec. 1954, 118, 385.

4. Farr, R. S. The febrile response upon injection of bovine albumin into previously sensitized rabbits (abstract). J. clin. Invest. 1958, 37, 894.

5. Bozicevich, J., J. J. Bunim, J. Freund, and S. B. Ward. Bentonite flocculation test for rheumatoid arthritis. Proc. Soc. exp. Biol. (N. Y.) 1958, 97, 180.
6. Wolff, S. M., S. B. Ward, and M. Landy. Serological properties of bentonite particles coated with microbial polysaccharides. Proc. Soc. exp. Biol. (N. Y.) 1963, 114, 530.

7. Farr, R. S. A quantitative immunochemical measure of the primary interaction between I*BSA and antibody. J. infect. Dis. 1958, 103, 239.

8. Grabar, P., and C. A. Williams. Méthode permettant l'étude conjuguée des propriétés électrophorétiques et immunochimiques d'un mélange de protéines; application au sérum sanguin. Biochim. biophys. Acta (Amst.) 1953, 10, 193.

9. Scheidegger, J. J. Une micro-méthode de l'immunoélectrophorèse. Int. Arch. Allergy 1955, 7, 103.

10. Farr, R. S. Fever as a manifestation of an experimental allergy (abstract). J. Allergy 1959, 30, 268.

11. Van Genderen, H., and H. H. M. Durville. Some aspects of the fever-producing action of purified bacterial pyrogens and non-bacterial antigens (abstract). Acta physiol. pharmacol. neerl. 1957, 5, 349.

12. Brittingham, T. E., and H. Chaplin, Jr. Febrile transfusion reactions caused by sensitivity of donor leukocytes and platelets. J. Amer. med. Ass. $1957,165,819$.

13. Jandl, J. H., and A. S. Tomlinson. The destruction of red cells by antibodies in man. II. Pyrogenic, leukocytic and dermal responses to immune hemolysis. J. clin. Invest. 1958, 37, 1202.

14. Stetson, C. A., Jr. Studies on the mechanism of the Shwartzman phenomenon. Similarities between reactions to endotoxins and certain reactions of bacterial allergy. J. exp. Med. 1955, 101, 421.

15. Hall, C. H., Jr., and E. Atkins. Studies on tuberculin fever. I. The mechanism of fever in tuberculin hypersensitivity. J. exp. Med. 1959, 109, 339.

16. Uhr, J. W., and M. W. Brandriss. Delayed hypersensitivity. IV. Systemic reactivity of guinea pigs sensitized to protein antigens. J. exp. Med. 1958, 108, 905.

17. Mulholland, J. H., S. M. Wolff, A. L. Jackson, and M. Landy. Quantitative studies of febrile tolerance and levels of specific antibody evoked by bacterial endotoxin. J. clin. Invest. 1965, 44, 920.

18. Farr, R. S. Personal communication.

19. Grey, H. M., W. Briggs, and R. S. Farr. The passive transfer of sensitivity to antigen-induced fever. J. clin. Invest. 1961, 40, 703.

20. Wolff, S. M., J. H. Mulholland, and S. B. Ward. Quantitative aspects of the pyrogenic response of rabbits to endotoxin. J. Lab. clin. Med. 1965, 65, 268. 